\title{
Breaking the Chains of Transactionalism: A Village Election without Money Politics in Panggungharjo
}

\author{
Longgina Novadona Bayo ${ }^{1}$ and Purwo Santoso ${ }^{2}$
}

Received: 2 May 2019 | Accepted: 25 November 2019 | Published: 20 December 2019

\begin{abstract}
The logic of corruption has seemingly been accepted as a normal part of democratic practices. This article challenges this logic, referring to the successful example of Panggungharjo, a village on the outskirts of Yogyakarta. ${ }^{3}$ Without romanticising this village and its experiences, this article seeks to show the decisions and steps necessary for realising change and breaking the chains of transactionalism. Change is only possible if both the supply of and demand for money politics are cut off. Transformation is only possible when changes occur in supply and demand. In other words, transactionalism can only be avoided in electoral politics when a shift in demand coincides with the stigmatisation of transactional practices.
\end{abstract}

Keywords: anti-vote buying, money politics, village chief elections

This article seeks to understand how the anti-money politics movement ${ }^{4}$ intersected with electoral contestations in a Yogyakarta village, as well as the important role of this movement in stimulating

1 Longgina Novadona Bayo is a lecturer at the Department of Politics and Government, Faculty of Social and Political Sciences, Universitas Gadjah Mada, Indonesia. She may be contacted at: novabayo@ugm.ac.id

2 Purwo Santoso is a professor of political science at the Department of Politics and Government, Faculty of Social and Political Sciences, Universitas Gadjah Mada, Indonesia. He currently also serves as the rector of Universitas Nadhlatul Ulama, Yogyakarta, Indonesia. He may be contacted at: psantoso@ugm.ac.id

3 Administratively, Panggungharjo is part of Bantul Regency. However, it is sociologically a sub-urban part of Yogyakarta City.

4 The literature has defined money politics in various ways, both broadly and narrowly. Broadly defined, money politics may be understood as corrupt practices such as politicians' receipt of bribes and other funds from investors and capital holders (Aspinall \& Sukmajati, 2015 , p. 3). This article uses a narrower definition, understanding money politics as the distribution of cash or goods to voters during candidates' electoral campaigns (Aspinall \& Sukmajati, 2015, p. 3). It focuses on the use of vote buying, which is "widely characterised as a phenomenon in which party workers or brokers target specific individuals whose preferences are known to them ex ante" (Finan \& Schechter, 2012; Nichter, 2008; Stokes, 2005). 
changes that had been considered impossible. Electoral democracy, which has long been identified as a central part of good governance, inexorably involves contestation. As such, many candidates have taken the shortcut of providing money to potential voters; at the same time, many voters have sought financial compensation from candidates. As Aspinall and Berenschot (2019) have argued, democracy is for sale, and voters and candidates are both unable to escape the cycle of vote buying and pragmatic politics.

This article explores how an Indonesian village broke the chains of pragmatism and money politics by avoiding the practice of vote buying, rather than transforming itself to avoid corrupt practices. This case study will pave the way for new studies that consider the paradigms and perspectives of practitioners, as it recognises that transformation occurred through the candidate's initiative. In this case, the candidate's actions were deeply rooted in his own background as an activist, as well as his efforts to dedicate himself to service and promote his values.

To avoid the pitfalls of over-generalisation, it is important to forefront the unique characteristics the case. This article takes as its case study Panggungharjo Village, the site of one of Yogyakarta's important historical monuments: Panggung Krapyak. ${ }^{5}$ Geographically, Panggungharjo is located within Bantul Regency; however, owing to its location on edge of Yogyakarta City, it is also highly urban. It is "divided" by ring road, and surrounded by two of the major roads that connect Yogyakarta with Bantul (the seat of Bantul Regency). The majority of Panggungharjo's residents are

\footnotetext{
Panggung Krapyak cannot be separated from the Yogyakarta Palace (also known as Kraton Yogyakarta), both within the context of Yogyakarta as an urban centre and within the context of Yogyakarta as a macrocosm. Panggung Krapyak is located along an imaginary axis that divides the province (linking Mount Merapi - Pal Putih Monument - the Yogyakarta Palace- Panggung Krapyak - South Sea). This axis is understood as a metaphor for the human experience, from birth through death. Completed in 1788, Panggung Krapyak was the last building completed by Sultan Hamengkubuwana I (also known as Prince Mangkubumi). This two-storey building, which includes nine segments and four doors (one in each compass direction) was designed to shelter the sultan and his family during their deer hunts (Prasetya, 2007, p. 1).
} 
senior high school graduates; many have also had some tertiary education. The village is the site of several Islamic boarding schools, as well as some university campuses. From this overview, it is clear that Panggungharjo is well-exposed to opportunities for change.

\section{The inevitability of transactional politics?}

Academic literature on electoral politics has been dominated by studies of money politics, wherein the logic of corruption is conditioned by patronage (Scott, 1977; Slater, 2004; Mietzner, 2007; Tomsa dan Ufen, 2013; Stokes, Dunning, Nazareno \& Brusco, 2013; Shin 2015; and Aspinall \& Sukmajati, 2016) and pragmatism (Ambardi, 2009). There has been a fundamental lack of concern, both among candidates and voters, for programmatic policies and activities. A study by Burhanudin Muhtadi, for example, found that one in three Indonesian voters had been involved in money politics during the 2014 elections (Muhtadi, 2018). ${ }^{6}$ Money politics does not only occur in national and local politics; it is also rampant in villagelevel elections throughout the country (Aspinall \& Rohman, 2017; Fitriyah, 2015; Halili, 2009). It is rare for studies to explore how Indonesians attempt to avoid money politics, with one of the few exceptions being an investigation of the village chief elections in Kulon Progo, Yogyakarta by Mas'udi \& Kurniawan (2017), which found that the practice of money politics could be prevented with programmatic policymaking.

Much of the literature in Indonesia has focused on explaining the character of money politics (patronage, clientelism, etc.). As such, one of this study's most important contributions is its exposition of methods for breaking the chains of money politics. This study understands the practice of money politics as part of a system of supply and demand, and thus argues that both supply and

Fearing that money politics would be widely practiced in the 2019 general election, the Yogyakarta Election Commission spent a year campaigning against vote buying. This programme began at the lowest level of government - the village level—and involved the declaration that several Yogyakartan villages were "anti-money politics". 
demand must be transformed to break its chains.

To avoid the above trap, this study refers to Finan \& Schechter (2012), who argue that vote buying becomes widespread when there is a high level of reciprocity in social relations. Vote buying does not occur in a vacuum; rather, this morally objectionable practice happens when the local culture expects and promotes transactionalism. Such a culture of reciprocity makes it difficult to promote change, such as that necessary for elections that are free of vote buying. As such, this study recognises change as involving two elements: (1) efforts to reduce the demand for vote buying and (2) efforts to promote alternatives to vote buying, thereby promote supply-side transformations.

Drawing from this argument, it is necessary to recognise that supply and demand have continued to intersect, thereby promoting the practice of vote buying and continuation of pragmatic politics in elections. Supply and demand are understood not as economic phenomena, but rather as political constructs. The practice of money politics cannot occur without the intersection of supply (from candidates) and demand (voters/constituents). To avoid the practice of money politics, it is thus necessary to disrupt these intersectionsas seen in the political strategies used in Panggungharjo.

Reciprocity does not occur only between candidates, but also between candidates and their voters. As argued by Stokes (2007) within elections this reciprocity occurs when power relationships are inequal. When their votes are bought, voters lose the power to shape public policy or promote their interests, having exchanged this power for cash or goods. Vote buying is used predominantly to gain voter support, but at the same time it limits candidates' accountability to their constituents. Such a lack of accountability leaves candidates and their constituents vulnerable to corruption (Vicente, 2014).

Several studies have confirmed that the practice of money politics is particularly effective in poor or financially vulnerable communities, and less-educated people (Brusco et al. 2004; Carkoglu 
\& Aytac, 2015). According to Stokes (2007), such communities have limited space to become involved in political decision- and policy-making, even when they themselves are the targets, and cannot ensure candidates respond to their needs. When this occurs, democracy is tainted; a central tenet of democracy is that all citizens should have the same political rights and opportunities. Recognising the deleterious effect of money politics on democracy and democratic practice, it is therefore necessary to break its chains and promote a more equitable political climate.

Several means of ending the practice of money politics have been discussed in the literature. First is programmatic politics (Mas'udi \& Kurniawan, 2017; Wyatt, 2013), which involves the (re) distribution of public goods to all citizens-no matter who they voted for (Stokes, 2007); as such, inclusivity is key. Conversely, in money politics, cash and goods are distributed solely to citizens who voted for a candidate or party. In their study of the 2017 local election in Kulon Progo, Mas'udi \& Kurniawan (2017) showed that candidates can use programmatic politics to eliminate vote buying and clientelism, as this approach can help citizens escape the cycle of money politics.

Meanwhile, taking Tamil Nadu, South India, as an example, Wyatt (2013) showed that politicians and political parties have begun favouring programmatic policies as a means of mobilising voters. They have attempted to stop their long-standing practice of vote buying, recognising that the competitive party system has facilitated programmatic politics. Politicians who disapprove of clientelism have sought to create trust and close relationships with programmatic policies, and as such programmatic strategies have become popular means of creating and maintaining support. The competitive party system has thus promoted the expansion of programmatic policies.

Second, civil society organisations have sought to avoid vote buying by empowering voters. Studying an illegal settlement in Solidaridad, Mexico, Holzner (2003) found that civil society 
organisations have attempted to employ informal and non-political means (including empowerment programmes, social services, and public goods such as land certification and clean water) to ensure that communities no longer depend on patronage to access State resources and services. COMVIVE was among the non-political organisation that contested these resources, while patronage structures were created in part through the Institutional Revolutionary Party (PRI). Although COMVIVE was unable to entirely sever the link between voters and PRI, it was able to reduce their dependence on the State by improving their capacity and autonomy.

Third, vote buying practices can be mitigated through political education (Schaffer, 2005; Vicente, 2014), which is most commonly done by the State. However, the effectiveness of such education is rarely measured. A study conducted by Vicente (2014) in Africa found that political education has a positive effect on voters, as it teaches them to vote in accordance with their consciences. In Africa; however, it has not reduced the effect of vote buying. Conversely, Schaffer (2005) has found that political education has had a different effect in the Philippines. Different understandings of vote buying have resulted in clashes between the reformist-minded middle classes and the vulnerable lower classes. Consequently, those who have promoted reform have been labelled the upper-middle class, while practitioners of vote buying (i.e. those who sell their votes) have been branded lower-class (poor). This class division has created a new political culture, one that has distorted Filipinos' political perspectives and activities (Schaffer, 2005, p. 6)

There also exists a new political phenomenon, an anti-moneypolitics movement that began at the grassroots, at the village level, the lowest level of government in Indonesia. When we conducted research in Panggungharjo Village, Sewon District, Bantul Regency, during its 2018 elections, we found no evidence that vote buying had occurred in the village. In Panggungharjo's past two elections, the victorious candidate did not use money politics to gain (or regain) office. This article, thus, attempts to answer a simple question: why 
was money politics, in the form of vote buying, not used or found during the 2018 Panggungharjo election? How was this election conducted without any money politics?

This research finds that the chains of money politics were severed for three reasons. First, our study in Panggungharjo has shown that the chains of money politics are broken when supply and demand are disrupted simultaneously. As shown in our above review of the literature, the practice of money politics (including vote buying) occurs because supply (parties/candidates) and demand (voters) are maintained within the political system. Unfortunately, however, many efforts to combat money politics have focused solely on one of these aspects (either supply or demand). As such, one of this study's most important contributions is the perspective that money politics functions within a transactional system that involves both supply and domain. Within this framework, it is also important to understand that Panggungharjo has institutionalised popular control of the practice of money politics. This underscores the fact that breaking the chains of money politics does not only require agency, but also a structure that offers collective control as a means of preventing vote buying.

Second, the practice of money politics shows that the logic of corruption, as created through patronage and pragmatic politics, evidences the vulnerability of political representation. In other words, the stronger the patronage, the weaker the political representation. From the case of Panggungharjo, we can see that political leaders' use of programmatic policies and political representation can help break the chains of money politics.

Third, the case of Panggungharjo shows that money politics and economic resources are not the most significant factors influencing candidates' electoral victories. In Panggungharjo's 2018 village election, money politics was relatively irrelevant. Economic capital is thus but one resource for political contestation. Candidates' financial resources are not their most significant assets; more important is their ability to convert this capital into symbolic 
power. In Panggungharjo, the chains of money politics were severed not solely by pragmatic policies that left money irrelevant, but also by the candidate's sophisticated use of the 'scare-off effect' to create 'puppet candidates' in the 2018 village chief election. In this case, the 'scare-off effect' did not stem from an incumbency advantage, but rather from supra-village networks that formed through the incumbent's accumulation of social capital.

\section{The experiences of Panggungharjo}

Panggungharjo is a sub-urban part of Bantul Regency. Many of its residents have abandoned agriculture and sought employment in other sectors. The majority of residents are private-sector employees (39\%) and labourers (38\%); only 4\% of village residents (750 people) work in agriculture (Monografi Desa Panggungharjo, 2018). Panggungharjo's location on the border of Yogyakarta City has significantly contributed to the rise of non-agrarian sectors such as service, trade, and industry. At the same time, the sociological conditions of Panggungharjo resemble those of Yogyakarta City more closely than those of Bantul's more rural areas. Owing to the village's sub-urban character, its residents are well-exposed to outside influences; consequently, its people are relatively open and willing to embrace change.

In its elections, Panggungharjo has had experience with money politics. This can be traced at least as far back as the 1992 village election, during which voters received between $\mathrm{Rp} \mathrm{10,000}$ and $\mathrm{Rp}$ 50,000 each; lower amounts were generally received by the village youths, while the elders-especially the men-received higher amounts $\left(\mathrm{TS}^{7}\right.$, interview, November 19, 2018; $\mathrm{BT}^{8}$, interview, November 19, 2018). Ultimately, the winner of Panggungharjo's 1992 spent approximately Rp 50,000,000 buying votes. By 2012,

\footnotetext{
Village resident.

Village resident.
} 
this amount had increased significantly; candidates spent an average of $\mathrm{Rp} \mathrm{300,000,000} \mathrm{each} \mathrm{on} \mathrm{vote} \mathrm{buying} \mathrm{(Hestiwiningsing,} \mathrm{2017,} \mathrm{p.}$ $3)$.

The rise of vote buying in Panggungharjo is inexorably linked to a corruption case that involved the village's previous chief, Siti Sremah Sri Jazuli, wholed Panggungharjo in the 1980s. The daughter of Broto Asmoro, who led Panggungharjo for three decades (from the 1950s through 1979), Sri Jazuli had become village chief after her father chose not to stand for re-election. As such, for the better part of four decades Panggungharjo was led by a family of local elites (WS ${ }^{9}$, interview, October 15, 2018).

In her first years as village chief, Sri Jazuli was seen as an exemplary leader, even being honoured as such by the national government. However, she was later proven to have embezzled money from the village government. As a result, she was replaced by Joko Djaelani, who served as acting chief until 1990. Residents believed that, to avoid any further practice of corruption, they needed to choose a leader with significant financial capital. The election was thus won by Samidjo, one of the village's wealthiest residents; a sugarcane farmer, he owned 70 hectares of farmland and employed many locals (WS, interview, October 15, 2018). He soon became an ATM of sorts, using his personal money to fund village activities when government funds fell short (Hestiwiningsih, 2017, pp. 4041). As such, accountability became secondary. Instead, patronclient relations were used to maintain villagers' loyalty, while village activities relied significantly on Samidjo's benevolence.

At the same time, however, residents became less involved in village policymaking. Villagers' proposals were only rarely transformed into policy, while bureaucratic and administrative services were sluggish. Consequently, residents became apathetic, caring little for the village government or its mechanisms. Nonetheless, the clientelist conditions that Samidjo created in the

Village elder. 
village enabled him to draw significant support during his almost twenty years as village chief (serving from 1992-2000 and 20022012). In 2012, recognising his deteriorating health and his advanced age, Samidjo chose not to run for re-election.

From Panggungharjo's previous experiences with money politics, it may be concluded that patron-client relations, as created through dependence on resources, were primary drivers of transactionalism. However, as Panggungharjo became increasingly modernised and its people gained greater access to information, the village became increasingly sub-urban. Levels of education increased, as did political literacy. This was stimulated in part by residents' political apathy, which had been cultivated through two decades of Samidjo's leadership. Increased political literacy may be understood as having limited undemocratic political practices such as money politics.

This is evidenced in Panggungharjo's 2012 election, whichuncontested by the incumbent-saw intense competition. Ultimately, Wahyudi Anggoro Hadi emerged victorious and became the village chief of Panggungharjo. He was seen as the opposite of Samidjo, both in his campaign activities and his leadership. Wahyudi had a background as an activist and significant intellectual capacity, and was thus deemed to possess significant political skills despite his young age; he was only 33 when he was elected. Unlike Samidjo, Wahyudi was not one of Panggungharjo's elites; his father was a civil servant, while his mother was a merchant at the local market. Given this background, it was not surprising that Wahyudi remained close to the village people, presenting himself as a simple man of the people. This popular image was complemented by his background as an activist.

Wahyudi's leadership abilities and skills were derived from his lengthy experience with activism, both as a university student and as a santri under Indonesia's largest Islamic organisation, the Nahdlatul Ulama (NU). Wahyudi was trained as a pharmacist, having graduated from the Faculty of Pharmacy at Universitas 
Gadjah Mada. While a student, he served as the chairman of the faculty's Student Senate (1998-1999), then as the chairman of the university's Movement of Indonesian Muslim Students (Pergerakan Mahasiswa Islam Indonesia, PMII) branch (1999-2000). Wahyudi had also studied at several Islamic boarding schools in Bantul. He later became the Deputy Secretary of NU's Service and Health Division (Lembaga Pelayanan dan Kesehatan NU, LPKNU), the manager of the organisation's Bantul branch (2009-2014), and a staff member of the Asnor youth movement's Education, Research, and Technology Division (2011-2016).

Wahyudi had also become a social activist, especially following the severe earthquake that struck Bantul in 2006. Wahyudi organised the village youths and worked together with local university students to establish a cultural community and promote a child-friendly hamlet as a means of promoting healing while simultaneously preserving traditional games. It is this concern for Panggungharjo that drove Wahyudi to contest the 2012 village election.

Owing to his leadership, particularly the programmatic policies and bureaucratic reforms he initiated during his first term (2012-2018), Wahyudi won re-election in 2018 with $88 \%$ of the vote. He thus maintained his position as the leader of Panggungharjo.

\section{Breaking the chain of money politics: negotiating new ethics}

Within the political constellation of Panggungharjo, money politics had been practiced for decades as a means of cultivating public support. However, the 2012 village election was marked by opposition to money politics, which created a new ethical standard. As the incumbent did not seek re-election, Panggungharjo's 2012 election was hotly contested by four candidates: (1) Agung Setiawan, an entrepreneur from Kweni Hamlet (dusun); (2) Putra Setiyarta, a two-term member of the Panggungharjo Village Council (2002-2008 and 2008-2012) from Pandes Hamlet; (3) Wahyudi Anggoro Hadi, 
a pharmacist from Pandes Hamlet; and (4) Yulianta, a private-sector employee from Glugo Hamlet. Of these, only Wahyudi promoted a new ethos that rejected money politics.

In the early weeks of the campaign, several candidates attempted to buy votes; one candidate stated that he had paid $\mathrm{Rp}$ 300,000 to people who voted for him. An envelope filled with money and a candidate's photograph was also discovered (Hestiwiningsih, 2017 , p. 44). However, not all of the candidates relied on vote buying to mobilise support. Wahyudi Anggoro Hadi rejected the practice of vote buying, choosing instead a programmatic approach; he again used this strategy during the 2018 election. As such, money politics became ineffective in Panggungharjo's elections.

Ultimately, Wahyudi Anggoro Hadi won Panggungharjo's 2012 election with 5,308 votes (44.52\% of all valid votes); Agung Setiawan received 2,569 votes (23.54\%), Putra Setyarta received 2,459 votes $(20.62 \%)$, and Yulianta received 1,588 votes $(13.32 \%)$ (Hestiwiningsih, 2017). The 2018 election, meanwhile, was contested by two candidates: the incumbent Wahyudi Anggoro Hadi and the challenger Abdul Latef. Wahyudi again emerged victorious, receiving 11,558 votes ( $88 \%$ of all valid votes cast); Latef only received 1,481 votes (12\%). This significant margin shows that Wahyudi and his programmatic policies were particularly effective.

Several correlated factors contributed to the limited effect of money politics on Panggungharjo's recent elections: (1) increased demand for change, through the stigmatisation of money politics on both the supply and demand side; (2) increased capacity for repression; (3) reduced potential for political clientelism; and (4) the replacement of clientelistic exchanges with programmatic exchanges. These factors not only show Wahyudi's capacity to go against the political mainstream, but also his ability to create popular control and political conscience through sophisticated intimidation. 


\section{Stigmatisation: Calling for Change}

In 2012, when he first decided to run for village chief, Wahyudi recognised that he lacked the financial capacity of his competitors. As such, he decided to adopt an anti-money politics strategy, one that also incorporated political education. To break the chains of money politics, he needed to first create a collective demand for change. For this, he sought to stigmatise vote buying, both among candidates and among voters.

On the demand side, stigma was created by increasing voters' recognition of the value of their votes. For example, during his antimoney politics campaigns, he compared the average amount paid for votes (Rp 50,000) with the price of a night with a sex worker. He also said that, by simply paying Rp 50,000 per voter, one could lead Panggungharjo for six years; ultimately, this meant that voters received only $\mathrm{Rp} 23$ per day.

... so I said to them, they've already set a price for their votes, $R p$ 50,000, and I somewhat crassly said that a whore in Pasar Kembang (a red-light district in Malioboro, Yogyakarta) is only Rp 150,000 a night; you are no better than a whore in Pasar Kembang. I maintained my dignity, but this could have cost me a lot of votes... ${ }^{10}$ (Wahyudi Anggoro Hadi, interview, October 9, 2018).

... Heed me; your vote is worth less than a whore at Pasar Kembang. At Pasar Kembang, people pay $R p$ 150,000 for two hours, and you only value yourself at $R p$ 50,000 for six years. So you cannot protest for six years. That's what he always said in his campaigns ${ }^{11}$ (EP, interview, October 8, 2018).

Wahyudi Anggoro Hadi regularly made statements such as "your vote is worth less than a whore at Pasar Kembang" during

10 Original: ... jadi ketika saya meminta dukungan, masyarakat pun sudah menetapkan berapa harga suara mereka yaitu satu suara 50.000, tetapi saya jawab dengan kasar kalau lonte di Sarkem 150 ribu, sedangkan Anda menggadaikan suara Anda 50.000 maka Anda tidak lebih baik dari lonte di Sarkem. Saya ini menjaga martabat, tapi resikonya saya kehilangan banyak suara ...

11 Original: ... Hargailah aku, harga suaramu itu lebih kecil dari lonte di Sarkem. Di Sarkem saja 150 ribu untuk dua jam, dan kamu cuma hargai dirimu 50 ribu untuk 6 tahun. Kamu tidak boleh protes selama 6 tahun. Itu selalu disampaikan dalam kampanye kampanye. 
his campaign activities. Such provocative discourses were promoted during prayer groups, campaign activities, and personal visits with residents. Such statements became integral in the repertoire of the anti-money politics movement in Panggungharjo. Wahyudi also used political education to transform social norms, hoping to teach constituents about the importance of clean elections and clean leadership. He hoped that such beliefs would be embraced by the people of Panggungharjo.

Owing to his limited financial capacity, Wahyudi used a new paradigm, offering to undertake a workload equivalent to the amount paid by candidates. In other words, he promised that he would provide social investments of equal or greater value than the money paid by his competitors. It is through this logic that Wahyudi reached voters.

I tried to create political opposition to money politics by offering services equivalent to the amount paid by my competitors. At the time, a candidate was offering $R p$ 300,000 per vote. I only had 30 days, so I divided $R p$ 300,000 by 30. The value of my services was thus equivalent to the money offered by my opponents. I held discussions, seminars, became a speaker... the important thing was that I kept working. Held congregational prayers at all of the mosques. ${ }^{12}$ (Wahyudi Anggoro Hadi, interview, October 9, 2018).

In short, he sought to create networks and social capital equivalent to the financial capital used by his opponents, and by doing so broke the chains of money politics. Through this discourse, Wahyudi also sought to transform the political norms and values of the local populace. He introduced a new ethical standard, one that gave leaders' performance more emphasis than their financial capacity.

The programmes that Wahyudi offered during his campaign

12 Original: Upaya yang dilakukan untuk melakukan perlawanan politik uang harus sebanding dengan uang yang dikeluarkan. Waktu itu, ada satu calon menyediakan angka awal 300 ribu (rupiah). Saya hanya punya waktu 30 hari, maka 300 ribu saya bagi 30. Kapitalisasi atas usaha ini kurang lebih sama dengan uang yang kita lawan. Saya diskusi, seminar, dan menjadi narasumber, yang penting kerja. Shalat jamaah di semua masjid. 
also reflected his view that the village government had created social distance through its programmes. He saw the bureaucracy as having performed poorly, as well as generally unwilling to respond to constituents' needs. As such, bureaucratic reform was a cornerstone of his political campaign. His goal was relatively simple: to manifest the State in the village by providing public services and public goods that respond to constituents' needs.

At the same time, he sought to stigmatise money politics on the supply side by asking the election committee to draft an agreement that candidates would not use money politics, and that anyone found to practice vote buying would be disqualified. This programme was reinforced by repressive endeavours, which will be discussed below.

\section{Increasing Repressive Capacities}

As another means of breaking the chains of money politics, the candidate increased his repressive capacity. He did not attempt to limit the supply of money politics through formal means, such as by reporting cases of vote buying to election authorities, but rather through informal mechanisms.

Central to his campaign team were two of his family members. First was NRB, a former member of the Bantul Parliament (20042009) and member of the National Awakening Party (Partai Kebangkitan Bangsa, PKB). NRB contributed positively to the candidate's popularity in the 2012 election. Second was EPB, a member of the Democratic Party of Indonesia-Struggle (Partai Demokrat Indonesia-Perjuangan, PDIP), who was part of their extended family. These core members of Wahyudi's campaign team managed Wahyudi's political strategies during the 2012 election. Also on his campaign team were a group of sapu kawat ${ }^{13}$ who

13 This team of sapu kawat (literally 'wire brooms') consisted of people who had been dismissed from the local PDIP sub-branch by the party's regional council because they refused to support Sri Surya Widati (the wife of Idham Samawi, a former regent) during the regional election. Partly because of their lack of support, Sri Surya Widati 
actively employed repression as a means of constraining the practice of money politics.

In the 2012 election, the candidate with the most significant financial capacity was PS, a member of the Panggungharjo Village Council as well as an important figure in the Community Empowerment Agency at the village ${ }^{14}$ and provincial level $;{ }^{15}$ he had also served as chairman of PDIP's sub-branch. To counter PS's financial and political resources, Wahyudi and his team employed a number of disillusioned PDIP members to mobilise support at the grassroots. Through the support of these PDIP members, he was able to (for example) make significant inroads in Sawit Hamletwhich had significant pro-PDIP leanings, and thus was expected to back Putra Setiyarta-despite his brother's PKB membership.

Generally, anti vote buying campaign used two types of repression and intimidation. First, they actively prevented other candidates' staff from distributing money to voters, thereby mitigating the effect of money politics. Many of his team were driven to do so by their personal vendettas against PS, who had never supported them during his time as chairman of Panggungharjo's BKM.

was defeated in the election by Suharsono (who was backed by the Greater Indonesia Movement Party [Partai Gerakan Indonesia Raya, Gerindra], PKB, and the Prosperous Justice Party (Partai Keadilan Sejahtera, PKS). In Panggungharjo, these former party administrators had backed Suharsono. Consequently, tension existed between them and PS, a loyal PDIP cadre who had supported Sri Surya Widati. Meanwhile, despite being an important member of the local PDIP branch, EPB had not backed the party's favoured candidate.

14 The Community Empowerment Agency (Badan Keswadayaan Masyarakat, BKM) is a local institution that was established through the National Programme for Community Empowerment (Program Nasional Pemberdayaan Masyarakat, PNPM). It was designed as a voluntary institution, one that exists independently of the government, and tasked with the local implementation of the PNPM. As its members, BKM takes local residents who have been recognized for their commitment to their community, including members of neighbourhood associations, social organisations, women's groups, and religious congregations. BKM has two functions: providing a means for communities to be involved in all development processes (planning, implementation, and evaluation) and representing local communities in interactions with stakeholders.

15 PS joined the BKM as secretary of the Panggungharjo office (2001-2005), later becoming its chairman (2005-2007), and coordinator (2007-2015). Afterwards, he was asked to lead the communication office at the regional level (2007-2015), provincial level (2012-2015), and national level (2012-2015). 
Second, these staff conducted 'black' campaigns, using psychological means to ward off vote buying. They stigmatised the practice of money politics, believing that this would lead his competitors to reconsider vote buying. As part of their campaign activities, team members created a situation that simulated vote buying, placing money and a photograph of a competitor in an envelope somewhere in Panggungharjo. This envelope was then 'discovered' by another member of Wahyudi's team, who then filed a report to the authorities. Through this means, the team scared voters and candidates away from money politics. Wahyudi's team recognised that this strategy was dishonest, but argued that shock therapy was the only way to prevent the practice of money politics.

"... Yeah, I was a bit mischievous. I spoke with one of my cadres, unknown to all, and provided a million rupiah. I provided a million rupiah as well as a photograph of one of my opponents. It was instigation, and the finding was reported to the police. That was a form of shock therapy, a warning; only one picture, and the police were involved. It wasn't enough for disqualification; just a warning. Even the voters didn't dare... they didn't ask for it, and if they weren't given any money, they'd accept it. That was the strategy. They needed shock therapy..."16 (EPB, interview, October 8, 2018).

Such actions were used by Wahyudi's team to seize control and prevent the practice of money politics. Repression was used as a form of 'shock therapy', a means of instilling a sense of fear in candidates and voters as well as creating a belief that all vote buying activities would be discovered and reported. In this manner, they undermined the effectiveness of money politics in village elections, arguing that repressive measures were necessary to lay the foundation for non-repressive elections that were free of money politics.

16 Original: ... Ya kita agak jahat. Jadi kita menyuruh salah satu kader kita yang tidak diketahui siapapun, dan kita modalnya satu juta. Kita kasih uang satu juta disitu ada satu tanda gambar salah satu calon. Kita adu domba, dan akhirnya dilaporkan ke polisi. Itu menjadi shock therapy kepada para calon. Ada peringatan. Hanya satu gambar dan dibawa ke polisi 'kan. Itu belum didiskualifikasi. Itu hanya sebagai peringatan. Masyarakat pun tidak berani. Masyarakat itu sebenarnya tidak meminta, tidak dikasih pun mereka menerima kok. Strateginya seperti itu. Harus diberikan shock therapy.... 


\section{Undermining Clientelism}

Wahyudi also sought to break the chains of clientelism by eroding the patron-client relationships between village chiefs and the Sultan. After being elected in 2012, he approached local village chiefs who had had land problems, promising that criminal offenses could be converted into administrative ones. Such land problems generally occurred when valuable village land-often located along the main roads of the regency-was sold without the knowledge of the sultan or the regency government strategic. He promoted the passage of village laws that granted village chiefs indemnity in the sale of village land, arguing that-when land sales occurred, this transfer became known by higher levels of government - such laws would protect them from criminal charges. These laws would convert criminal sanctions into administrative ones. However, also embedded in this promise was a subtle threat: those who failed to support Wahyudi could face legal consequences.

From the data we collected in the field, as well as from statements by Wahyudi himself, it is evident that he was relatively disliked by the Sultan of Yogyakarta (Wahyudi Anggoro Hadi, interview, October 9, 2018; BD, personal communication, December 12, 2018). For this, he cited his unwillingness to lease out land for sugarcane cultivation. He protected village land by using village bylaws that he understood to contradict with those of the Sultanate. Owing to their personal differences, the Sultan-despite his formal position as Governor of Yogyakarta - rarely attended local events to which he was invited.

\section{Transformations: Replacing clientelistic exchanges with programmatic exchanges}

Wahyudi made an important breakthrough in village-level politics by transforming clientelistic exchanges into programmatic ones. By implementing programmatic policies, Wahyudi created a new public ethos that positioned money not as an individual 
property, but rather something to be used for collective benefit. By framing money as irrelevant, he challenged the supply-side aspects of vote buying by stigmatising money politics and presenting himself (through his programmes) as a progressive visionary.

Ultimately, Wahyudi's programmatic policies were seen as fulfilling the community's needs. He created programmatic exchanges that transformed problems into solutions. During his first term as village chief, Wahyudi implemented several innovative social programs, initiating a social welfare programme, starting a waste-management programme, and establishing village enterprises.

First, in his social development policies, Wahyudi focused on providing education and healthcare services. For this, he created a new village agency, the Social Welfare Implementation Agency (properly known as Badan Pelaksana Jaring Pengaman Sosial Masyarakat, but commonly abbreviated Bapel JPS). He envisioned Bapel JPS as a "last-line of defence", a means of promoting social welfare even as national programmes such as the Healthy Indonesia Card (Kartu Indonesia Sehat) and Clever Indonesia Card (Kartu Indonesia Pintar) faltered. He recognised that many of Panggungharjo's poorer residents were not included in these national programmes, and as such these sub-urban poor required the village government's support.

Bapel JPS incorporated three components: education, maternal and child health, and persons with disabilities. The foremost part of the education component was the One House, One Graduate programme, which sought to improve vulnerable families' ability to send their children to university; this component also included special subsidies for school-age children. Meanwhile, to improve maternal and child health, the Bapel JPS programme worked together with several hospitals to provide women with nine prenatal examinations, a natural childbirth, and two post-natal examinations; new-borns were immunised through this programme. Bapel JPS also provided basic healthcare services and subsidies to elderly residents. Finally, the programme sought to provide support 
(such as wheelchairs) to people with disabilities; this component, however, remains in development as of writing (Hestiwiningsing, 2017, pp. 72-74).

Funding for Bapel JPS came from the village government, local fundraising initiatives, and third-party sponsors. Village funds for the Bapel JPS programme increased over time, from Rp 139,188,000.00 in 2016 to Rp 497,565,000.00 in 2017 and Rp $548,651,500.00$ in 2018 (APBDes Panggungharjo 2016, 2017, 2018). Meanwhile, local fundraising initiatives included both donations as well as religious tithes and alms (zakat, infaq, shodaqoh). Finally, third-party funding came predominantly from local enterprises' corporate social responsibility (CSR) funds programmes.

It is an open secret that, where companies seek to facilitate their business activities, they provide gratuities and bribes to village governments (read: the village chiefs); in Panggungharjo, this amount averaged between $\mathrm{Rp} 5$ million and $\mathrm{Rp} 15$ million. Previous village chiefs had taken this money as their own. Wahyudi, however, used it for government programmes (Hestiwiningsih, 2017, p. 75), asking that companies direct any investments to social programmes. From this review of his social programmes, it can be seen that Wahyudi used sophisticated means to transform clientelistic exchanges into programmatic exchanges, with clientelistic resources becoming collective properties.

Another one of Wahyudi's breakthroughs was the Association of Waste Management Groups (Kelompok Usaha Pengelola Sampah, KUPAS). Owing to its sub-urban nature, Panggungharjo faced significant waste issues; KUPAS was intended to resolve this problem. After the passage of Law No. 6 of 2014 regarding Villages, which promoted institutional reform, Wahyudi established a village-owned enterprise named Panggung Lestari (which included KUPAS as one of its units). Through these programmes, social welfare in Panggungharjo improved, as did waste management. Furthermore, by involving a local women's group in collecting dues and producing biodiesel, this programme helped empower village 
women (Hestiwiningsih, 2017, p. 69).

Central in Wahyudi's innovation was his use of Panggung Lestari to not only collect waste, but also as an extension of the village government, one responsible for directly dealing with residents, hearing their concerns, and identifying problems that required government involvement. For example, this village-owned enterprise helped some 70 local residents deal with debts they had incurred with a loan shark, creating a Legal Aid and Human Rights Advisory Post (Pos Pelayanan Hukum dan HAM, or Posyan KumHAM) to do so (Hestiwiningsih, 2017, p. 69).

Over time, Panggung Lestari expanded to sell various products, most prominently biodiesels made from waste cooking oil. Furthermore, as it helped improve villagers' welfare, it gained popular recognition and support. Over the years, this village-owned enterprise established new units and increased its assets considerably.

Table 1.

Income from Village-Owned Enterprises, 2016-2018

\begin{tabular}{|c|c|}
\hline Year & Budget (Rp) \\
\hline 2015 & $148,234,250.00$ \\
\hline 2016 & $1,228,504,097.00$ \\
\hline 2017 & $1,567,608,950.00$ \\
\hline 2018 & $4,844,365,450.00$ \\
\hline
\end{tabular}

Source: Village Enterprise Agency of Panggungharjo, 2016 and 2017, Report Compiled in 2018

As such, it is not surprising that Panggung Lestari was used as proof that Wahyudi had improved the village economy, and also taken by the national government as a model village-owned enterprise. This cannot be separated from Wahyudi's managerial abilities, which was facilitated by his installation of trusted friends in key positions. Through Panggung Lestari, Wahyudi hoped to deal 
with unemployment in the village; local residents were employed in waste management, waste cooking oil production, and filtration. The fact that the waste cooking oil produced by local residents was purchased to PT Tirta Investama (Aqua Danone) further shows that the village-owned enterprise was able to financially empower them.

From the various programmes developed by Wahyudi, it can be seen that he developed a new intimate leadership, one that sought to transform social problems into solutions. Because of this intimacy, Wahyudi's programmes were relatively well targeted, and thus better able to handle villagers' problems.

\section{Seizing Opportunities: Transforming Panggungharjo}

Wahyudi's programmes, as discussed above, were made possible by political opportunities that stemmed from crisis of government that Panggungharjo faced in 2012. Wahyudi seized this political opportunity to be elected as Panggungharjo's village chief in 2012, promising to transform the village government into a progressive and independent one. He promised that Panggungharjo would enjoy strong leadership, and have power that reached beyond its borders.

However, the transformations experienced by Panggungharjo did not stem solely from Wahyudi's personal leadership, but also the bureaucratic reforms he initiated. He believed that bureaucratic reform was necessary to ensure that village programmes could be properly implemented; in other words, he recognised that Panggungharjo could not be transformed solely through his programmes, but required a significant structural change as a means of 'forcing' village administrators to follow the new rules. Panggung Lestari's recognition as one of the best village-owned enterprises in Indonesia was only possible by the collective efforts of the village administrators, as well as technological advancements that facilitated transparency and accountability. 


\section{Bad Leadership}

As shown above, when Samidjo served as village chief, he relied on clientelism and created paternalistic relationships with his constituents. Under his leadership, the village lacked the funds to hold regular activities; when activities were held, they were funded with Samidjo's own money. Ultimately, the village government had little concern for public participation, accountability, or transparency, and these conditions provided fertile ground for money politics. Residents used elections for their own benefit, and thus sold their votes.

Recognising the incumbent's weak leadership, Wahyudi sought to transform Panggungharjo. In his first six years as village chief, he became prominent through his programmatic policies and bureaucratic reforms. Wahyudi believed that programmatic policies could only be properly implemented if the government was clean, accountable, and transparent; as such, bureaucratic reform was a central part of his campaign and his activities as village chief.

Wahyudi recognised that transforming Panggungharjo's bureaucracy and promoting his vision of a clean government required significant time. In his early years as village chief, Wahyudi faced resistance from village administrators. Few village staff had supported Wahyudi during the 2012 election, and most had failed to internalise the vision that he offered. Although he was generally quiet, he could speak quite loudly at time. His leadership style thus differed significantly from that of the previous leader.

Nonetheless, Wahyudi persevered. To establish close ties with his staff, he provided an example of the performance he desired, starting and finishing work on time. He was even willing to clean the toilets at the village hall. Wahyudi believed that, by practicing what he preached, he would surely transform the bureaucratic culture of the village. This proved true, and over time Panggungharjo's administrators began adhering to the new system.

Wahyudi recognised that he needed to transform 
Panggungharjo's bureaucratic culture in order to implement his programmes. He also realised that such a transformation could not be realised through personal example alone; he needed a means of ensuring that any transformations were maintained after his time as village chief ended. As such, Wahyudi passed Village Regulations (Peraturan Desa) No. 18 of 2015 regarding the Provision of Additional Incentives to Village Government Staff, which created a system of rewards and punishments for village administrators. Good performance would be rewarded, while poor performance would be punished. By providing an incentive for village administrators, this bylaw helped improve their welfare and imbued them with a new passion for their work.

Wahyudi also used information technology to facilitate transparency and accountability, hoping that this would minimise the practice of corruption in Panggung Lestari. Wahyudi understood that institutionalising collective control was necessary to maintain proper and democratic governance over the long term; although personal leadership capacity was necessary, popular control was needed to sidestep the trap of authoritarianism.

\section{New strong leadership and the scare-off effect}

Wahyudi's leadership was buttressed by the trust of his constituents, which he cultivated by initiating programmatic policies and establishing linkages at the district, regency, provincial, and even national level. Wahyudi, and Panggungharjo, became known throughout Indonesia. The village was widely referenced by village development programmes, and it received numerous awards. Under Wahyudi's leadership, Panggungharjo was identified as one of Indonesia's best villages. It was recognised, for example, as (1) one of Indonesia's best village and sub-districts in 2014; (2) an exemplary village in 2017; (3) a cultural village in 2017; and (4) a village that promotes education in 2016.

Furthermore, owing to Wahyudi's use of the 'scare-off effect', 
Panggungharjo's 2018 election was not hotly contested. This use of the scare-off effect did not stem from his incumbency advantage, but rather Wahyudi's extra-village networking and accumulating social capital. It is Wahyudi's ability to reach beyond Panggungharjo that enabled him to create a new political ethos, one that rejected money politics. Wahyudi's popularity provided him with new opportunities; at one point, it hosted a Ministry of Villages ceremony.

Recognising his popularity and his networks, Wahyudi expected that he would win a second term. Money politics, thus, became irrelevant in Panggungharjo's 2018 election, and potential opponents believed that they could not successfully challenge Wahyudi. As one resident said, "even if he'd just gone to sleep, he would have won" (BT, interview, November 19, 2018). Panggungharjo's 2018 election could thus be identified as essentially uncontested (see Lay, Hanif, Ridwan, \& Rohman 2017).

However, as electoral regulations require elections to be contested by at least two candidates, an opponent was necessary; otherwise, the village elections would be postponed, and the district government would appoint an acting village chief. As such, Wahyudi sought a 'puppet candidate', one who could formally contest the election but was not expected to win. Several informants stated that Wahyudi had chosen a puppet candidate to ensure that he could sustain his development and programmatic policies. A new leader, he feared, would be detrimental to Panggungharjo.

Now, the people all knew that Panggungharjo was the stick against which all other villages were measured. If there were only one candidate, the election would be postponed. The position of village chief would be occupied by a district staff member. And what, then, of the programmes we had developed? Under the leadership of an acting village chief, would they be maintained ${ }^{17}\left(\mathrm{TK}^{18}\right.$, interview, October 10, 2018).

17 Original: Sekarang masyarakat sudah tau semua kalau Panggungharjo itu sebagai tolak ukur oleh desa lain. Kalau sampai cuma ada satu kandidat, pemilihan akan ditunda. Posisi lurah akan diisi oleh orang dari kecamatan. Trus usaha yang sudah dirintis, kalau nanti diampu oleh orang kecamatan apakah akan bertahan?

18 Village resident. 
Panggungharjo had developed rapidly; every day there were comparative studies. As such, nobody dared contest the election. But if nobody ran, the chain of leadership would be broken, even though a lot of work was still necessary. If there were no opponent, elections would be postponed for two years. We feared that this would curb our development ${ }^{19}\left(\mathrm{LT}^{20}\right.$, interview, October 10, 2018).

Puppet candidates have been understood as necessary in noncompetitive elections; indeed, in some cases such candidates have even been paid by incumbents. In Panggungharjo's 2018 election, Latef was chosen as the puppet candidate. He had no desire to win the election or to compete against Wahyudi. As such, he prepared no campaign strategies and conducted no campaign activities; he saw himself simply as helping Wahyudi in the 2018 election.

LT understood his candidacy as necessary to continue the practice of democracy. As he stated, "I was just motivated to contest the election to maintain democracy. If nobody ran, democracy would end" ( LT, interview, October 10, 2018). He understood 'democracy' as a procedural democracy (Schumpeter, 1976), something built on a foundation of participation and competition (Dahl, 1973). For Latef, his decision to become a puppet candidate was a rational one, as only then could democracy be maintained.

\section{Breaking the Chains of Clientelism, Creating Political Representation}

From this discussion, it is clear that money politics, paternalism, and corruption are not eternal; they can be transformed. As shown by Wahyudi, it is possible to disrupt the supply and demand for vote buying simultaneously. However, such disruption is insufficient on its own; there must also be transformative leadership. Such leadership makes political representation possible, and thereby

19 Original: Panggungharjo belakangan ini maju pesat, setiap hari ada studi banding. Sehingga di pemilihan ini tidak ada yang berani maju. Kalau tidak ada yang maju, kepemimpinan terputus, padahal banyak yang harus dikerjakan. Kalau tidak ada lurah, maka akan diundur lagi, dua tahun. Takutnya peningkatan yang pesat menurun lagi.

20 Head village candidate. 
supports political transformation.

Money politics must be understood as existing within a system of exchanges and negotiations between supply and demand. As such, to break its chains it is necessary to disrupt both simultaneously and avoid interactions between them. In this case, the supply of money politics was disrupted through the use of repressive tactics in conjunction with collective control. Meanwhile, on the demand side, the practice of vote-buying was stigmatised, thereby stimulating anti-money politics discourse. By convincing candidates' to avoid vote buying, as well as by reducing demand for the practice, Wahyudi was able to break the chains of money politics.

Furthermore, Wahyudi recognised that simply severing the chains of money politics was inefficient. He knew that he needed programmatic policies and strong leadership to promote transformation to ensure that all villagers had the same access to resources and welfare schemes. Wahyudi's programmatic policies reached all elements of the community, and the social welfare scheme that he developed was able to concretely answer the problems of his constituents. The political promises that he articulated during his campaign were used to promote real social development.

In interviews, several informants stated that Wahyudi had established close relationships with the vulnerable and marginalised elements of local society, including persons with physical disabilities, widows, and the elderly ( $\mathrm{KR}^{21}$, Sub-village head, interview, October $7,2018)$. When campaigning, Wahyudi often visited these marginal groups, listening to their concerns and recognising their needs. During his first term as village chief (2012-2018), he implemented several programmes that targeted and empowered these groups, thereby improving their social welfare. This concern for the vulnerable was recognised by voters, who supported him and his programmes. As such, when Wahyudi decided to seek re-election,

21 Sub-village head. 
nobody dared challenge him. By ensuring that vulnerable elements of society were represented politically, he gained voter sympathy.

Wahyudi's concern for vulnerable groups, as manifested through his programmatic policies, was supported through his efforts to optimally use all available resources. He complemented these efforts by providing the village with new assets, as seen in his creation of Panggung Lestari. Over time, this village-owned enterprise provided Panggungharjo with significant income, which it used to fund its social welfare programmes. Important for Panggung Lestari's success was Eko Pambudi, its chairman, who was a member of Wahyudi's campaign team. Under his guidance, Panggung Lestari became a successful enterprise, one that was widely referenced throughout Indonesia.

As nearly all of Wahyudi's constituents benefited from the cornucopia of resources that became available to them, nobody dared against him when the incumbent ran for re-election. With no opponent, the election was uncontested, and thus money politics played no part in Panggungharjo's 2018 election. Villagers did not expect vote buying, as their own needs had been fulfilled by the programmatic policies that Wahyudi implemented during his first term. Money politics, thus, was undermined by programmatic politics.

At the same time, however, the people of Panggungharjo had become overly dependent on Wahyudi. As such, it was possible that-if Wahyudi were to step down, or choose not to seek reelection - the anti-money politics movement would be stopped dead in its tracks. During field observations, we spoke with a local resident who operated a small kiosk near the village hall; this informant told us that he 'missed' vote buying; "Now village chief elections are not like before. They don't use money anymore" (Panggungharjo resident, October, 8, 2018).

From this statement, it may be surmised that-if candidates were to attempt vote buying again - residents would be willing to accept their money and sell their votes. Conversely, if residents 
sought to sell their votes, candidates might buy them. This shows that, in the case of Panggungharjo, the leader's personal capacity was crucial. It is thus necessary to consider whether a true antimoney politics ethos has been created, or whether such practices endure during municipal and general elections.

\section{Conclusion}

Panggungharjo's was able to avoid money politics because one candidate, Wahyudi, disrupted the chain of money politics on both the supply and demand side. He began these efforts during the 2012 election by using repression and threats to convince his opponents not to attempt vote buying, thereby disrupting the supply of money politics; at the same time, he disrupted the demand for money politics by stigmatising vote buying. From the case of Panggungharjo, it is clear that the ouroboros of money politics can be slain when both supply and demand are disrupted simultaneously.

In breaking the chains of money politics, Wahyudi cleverly used programmatic policies and reached out to marginal groups in the community, including not only the sub-urban poor but also the elderly, the youths, and people with disabilities. He thus created a new ethos, one in which money was no longer framed as a personal property, but rather as something that provided collective benefit. He complemented this new ethos with bureaucratic reform and transformative leadership (Hestiwiningsih, 2017; Edi \& Wardhani, 2018). Ultimately, Panggungharjo was recognised as one of Indonesia's best villages.

Wahyudi's leadership approach, which combined threats and hard work, endured even after his election; furthermore, he was able to scale up these activities, further buttressing public trust in him and his work. Panggungharjo was recognised as one of Indonesia's best villages, with its village-owned enterprise Panggung Lestari being widely referenced throughout the country. As village chief, Wahyudi Anggoro Hadi gained respect at the municipal, provincial, and 
national level. Ultimately, during Panggungharjo's 2018 election, nobody was willing to actively campaign against him; to ensure that democracy continued, he thus chose a 'puppet candidate' to run against him. In such non-competitive elections, money politics were unnecessary. Vote buying and other forms of money politics were rendered irrelevant in Panggungharjo's village politics.

It may thus be concluded that money politics can be undermined when collective control has used to disrupt its supply and demand; in this case, Wahyudi used coercion and stigmatisation to prevent vote buying. By disrupting the link between supply and demand, he took village politics in a new direction: a low-cost electoral system that rejected vote buying. This new direction was complemented by programmatic policies that increased social welfare, particularly among the community's vulnerable elements.

From the case of Panggungharjo, it can be seen that Wahyudi did not only use agency to combat vote buying, but institutionalised his reforms so that villagers and subsequent leaders would continue to abide by these new rules and ethos. Wahyudi sought to ensure that his new system would continue to shape Panggungharjo's politics and development. However, further study is necessary to see whether these rules and ethos are maintained under a different regime, or during other elections (i.e. municipal and national elections).

\section{Acknowledgments}

The author would like to thank Edward Aspinall and Ward Berenschot for their comments, input, and recommendations, all of which helped hone this article into its present form. The author would also to express the greatest gratitude to Anak Agung Istri Tatik Rismayanti for assisting with the data collection during Panggunghajor's 2018 village election. 


\section{References}

Ambardi, K. (2009). Mengungkap politik kartel: Studi tentang sistem kepartaian di Indonesia. Jakarta: Kepustakaan Populer Gramedia.

Aspinall, E., \& Sukmajati, M. (2015). Politik uang di Indonesia: Patronase dan klientelisme pada pemilu legislatif 2014. Yogyakarta: PolGov.

Aspinall, E., \& Rohman, N. (2017). Village head elections in Java: Money politics and brokerage in the remaking of Indonesia's rural elite. Journal of Southeast Asian Studies, 48(1), 31-52.

Aspinall, E. \& Berenschot, W. (2019). Democracy for sale: Elections, clientelism, and the state in Indonesia. Ithaca: Cornell University Press.

Brusco, V., Nazareno, M., and Stokes, S.C. (2001). Vote buying in Argentina. Latin America Research Review, 39 (2), 66-88. DOI: https://doi.org/10.1353/lar.2004.0022.

Çarkog $\square$ lu, A., \& Aytaç, E. (2014). Who gets targeted for vote-buying? Evidence from an augmented list experiment in Turkey. European Political Science Review, 7 (04), 547-566. DOI: 10.1017/ S1755773914000320.

Dahl, R. A. (1973). Polyarchy. New Haven: Yale University Press.

Edi, A.C., \& Wardhani, I.S. (2018). Transformational and transactional leadership: Understanding how leadership cultivates democratic citizenship in Panggungharjo, Bantul, Yogyakarta. PCD Journal, VI(2), 239-269.

Finan, F., \& Schechter, L. (2012). Vote buying and reciprocity. Econometrica, $80(2), 863-881$.

Fitriyah. (2015). Cara kerja politik uang (studi kasus pilkada dan pilkades di kabupaten Pati). Politika: Jurnal Ilmu Politik, 6(2), 101-111.

Halili. (2009). Praktik politik uang dalam pemilihan kepala desa: Studi di desa Pakandangan Barat, Bluto, Sumenep, Madura. Jurnal Humaniora, 14(2), 99-112.

Hestiwiningsih, K. (2017). Kepemimpinan transformasional di tingkat desa: Studi gaya kepemimpinan Wahyudi Anggoro Hadi sebagai kepala desa Panggungharjo, kecamatan Sewon, kabupaten Bantul. Yogyakarta: UGM.

Holzner, C.A. (2003). End of clientelism: Changing political practices among the poor in Mexico. Texas: Meeting of the Latin American Studies Association.

Lay, C., Hanif, H., Ridwan, and Rohman, N. (2017). The rise of uncontested elections in Indonesia: Case studies of Pati and 
Jayapura. Contemporary Southeast Asia, 39 (3), 427-448.

Mas'udi, W., \& Kurniawan, N.I. (2017). Programmatic politics and voter preferences: The 2017 election in Kulon Progo, Yogyakarta. Contemporary Southeast Asia, 39(3), 449-469.

Mietzner, M. (2007). Party financing in Post-Soeharto Indonesia: Between state subsidies and political corruption. Contemporary Southeast Asia A Journal of International and Strategic Affairs, 29(2). 238-263.

Monografi desa Panggungharjo. (2018). Yogyakarta.

Muhtadi, B. (2018). Riset: Sepertiga pemilih Indonesia terima suap saat pemilu. Kompas.com. Retrieved from https://nasional.kompas.com/ $\mathrm{read} / 2018 / 07 / 24 / 06280031 /$ riset--sepertiga-pemilih-indonesiaterima-suap-saat-pemilu

Nichter, S. (2008). Vote buying or turnout buying? Machine politics and the secret ballot. American Political Science Review, 102 (1), 19-31.

Prasetya, L. Edhi. (2007). Re-emphasizing urban linkage continuity as an effort for conserving Panggung Krapyak, Yogyakarta. Paper presented at the International Seminar "The Knowledge City: Spirit, Character and Manifestation". Department of Architecture, University of North Sumatra, Medan.

Schaffer, F.C. (2005). Clean elections and the great unwashed. Paper Number 21 (Unpublished).

Schumpeter, J. (1976). Capitalism, socialism and democracy. London: Allen and Unwin.

Scott, J.C. (1977). Political clientelism: A bibliographical essay. In S.W. Schmidt, L.Guasti, C.H. Lande, J.C. Scott (Eds), Friends, followers, and factions: A reader in political clientelism (pp.483-505). Berkeley: University of California Press.

Shin, J. H. (2015). Voter demands for patronage: Evidence from Indonesia. Journal of East Asian Studies, 15, 127-151.

Slater, D. (2006). The ironies of instability in Indonesia. Social Analysis, 50(1), 208-213.

Stokes, S.C. (2005). Perverse accountability: A formal model of machine politics with evidence from Argentina. American Political Science Review, 99(3), 315-325.

Stokes, S.C. (2007). Is vote buying undemocratic. In F.C. Schaffer (Ed), Elections for sale: The causes and consequences of vote buying (pp. 8199). Boulder, Colorado: Lynne Rienner Publisher.

Stokes, S. C., Dunning, T., Nazareno, M., and Brusco, V. (2013). Brokers, voters, and clientelism: The puzzle of distributive politics. New York: 
Cambridge University Press.

Tomsa, D., and Ufen, A. (eds). (2013). Party politics in Southeast Asia: Clientelism and electoral competition in Indonesia, Thailand and the Philippines. New York: Routledge.

Vicente, C. (2014). Is vote buying effective? Evidence from a field experiment in West Africa. Economic Journal, 124, F356-F387.

Wyatt, A. (2013). Combining clientelist and programmatic politics in Tamil Nadu, South India. Commonwealth \& Comparative Politics, 51(1), 27-55. http://dx.doi.org/10.1080/14662043.2013.749674. 